DOI: $10.17951 / \operatorname{lrp} .2018 .37 .4 .49-65$

\author{
ANNA WiteK \\ Uniwersytet Marii Curie-Skłodowskiej w Lublinie \\ https://orcid.org/0000-0001-7990-1271 \\ Teresa LeWANDOWsKa-Kidoń \\ Wyższa Szkoła Pedagogiczna im. Janusza Korczaka w Warszawie \\ https://orcid.org/0000-0003-3942-4305
}

\title{
FUNKCJONOWANIE UCZNIA \\ Z TRUDNOŚCIAMI PRZYSTOSOWAWCZYMI \\ W ŚRODOWISKU SZKOLNYM W KONTEKŚCIE \\ POTRZEBY ROZWIJANIA INTELIGENCJI EMOCJONALNEJ
}

Streszczenie: Przekraczanie kolejnego progu edukacji, jak również codzienne sytuacje szkolne wywołują u uczniów przykre emocje. W konsekwencji przyczyniają się do zaburzenia samooceny, relacji z innymi osobami, spowalniają rozwój umiejętności emocjonalnych. Prowadzi to do trudności przystosowawczych, rozumianych jako dezaptacyjne reakcje na sytuacje stresowe. Te z kolei wiążą się z brakiem kompetencji społecznych.

Jak wynika z badań prezentowanych w literaturze polskiej i obcojęzycznej, uczniowie, w tym ze specjalnymi potrzebami edukacyjnymi, mają nierzadko problemy ze zdobywaniem umiejętności społecznych i emocjonalnych. W konsekwencji doświadczają trudności przystosowawczych, zarówno o charakterze indywidualnym, jak i społecznym. W artykule analizowane zagadnienie zobrazowano indywidualnym przypadkiem ucznia szkoły podstawowej ze zdiagnozowanymi mieszanymi zaburzeniami zachowania i emocji. Wskazano również na potrzebę konsekwentnego rozwijania umiejętności emocjonalnych od początku edukacji szkolnej.

Niwelowanie trudności przystosowawczych uczniów jest możliwe poprzez wspieranie ich w zdobywaniu kompetencji emocjonalnych, w tym inteligencji emocjonalnej. Dane naukowe dowodzą, że niektóre zdolności emocjonalne można zyskać w toku nauki. Inteligencja emocjonalna, jak każdy nowy konstrukt, budzi wiele kontrowersji, ale też nadziei, że z upływem czasu poznamy jej znaczenie w życiu człowieka.

Słowa kluczowe: trudności przystosowawcze, inteligencja emocjonalna, kompetencje emocjonalne, specjalne potrzeby edukacyjne 


\section{WPROWADZENIE I CEL PRACY}

Największą zmianą w życiu dziecka jest pójście do szkoły i przystosowanie się do panujących tam warunków oraz wymagań. Przebywanie w szkole kształtuje dziecięcą wiedzę, daje poczucie sprawczości, radość z osiąganych sukcesów, ale także niesie za sobą rozczarowanie, smutek, złość w sytuacji przeżywanej porażki. Te codzienne doświadczenia odpowiadają za postawę pracowitości, czyli sposób, $\mathrm{w}$ jak odnosimy się do zadań i obowiązków oraz radzimy sobie z organizacją własnej pracy. Mają również wpływ na wytrwałość w pokonywaniu przeszkód. Ocena własnej sprawczości w wykonywaniu zadań szkolnych oraz w kontaktach z rówieśnikami i dorosłymi decyduje o tym, jak u ucznia kształtują się samoocena i obraz siebie (Kaczan 2009, s. 152-157; Półtorak 2017, s. 71).

Przystosowanie to adaptacja do nowego środowiska, do nowych warunków oraz sytuacji, to umiejętność panowania nad środowiskiem, właściwej oceny i stawiania czoła trudnościom. To „zdolność organizmu do utrzymywania wewnętrznej równowagi (homeostazy) w środowisku zewnętrznym oraz dążenie podmiotu do układania zrównoważonych stosunków z otoczeniem społecznym” (Lubowiecka 2000, s. 16). Mowa tu o przystosowaniu osobowym, mającym wymiar subiektywny, pozwalający jednostce osiągnąć „poczucie zadowolenia i wewnętrznej satysfakcji” (Klus-Stańska 2004, s. 11) dzięki rozwijaniu własnego potencjału, kreatywności i otwartości na nowe doświadczenia (Bilewicz-Kuźnia 2015, s. 188). Wyróżnia się również przystosowanie społeczne rozumiane jako pełnienie ról społecznych zgodnie z oczekiwaniami otoczenia społecznego (Buchnat 2013, s. 15), polegające na dostosowaniu się do panujących w społeczności norm moralnych, przyzwyczajeń, zwyczajów, przekonań (Doroszewska 1989, s. 257).

Szkolne sytuacje oceniane przez ucznia jako trudne wywołują w nim lęk, frustrację, powodują niezaspokojenie potrzeb psychicznych (akceptacji, uznania, szacunku). W konsekwencji obniżają jego samoocenę, zmniejszają poczucie własnej wartości oraz skuteczności (Mudrecka 2013, s. 55), zaburzają relacje z innymi osobami, głównie rówieśnikami. Utrudniają rozwijanie umiejętności społecznych, takich jak radzenie sobie w sytuacjach stresowych czy zadaniowych, a także osłabiają motywację do nauki. Prowadzi to do zaburzeń przystosowawczych, rozumianych jako dezaptacyjne reakcje na sytuacje stresowe. Mogą one mieć charakter indywidualny lub społeczny, trwały lub przemijający, kiedy jednostka znajdzie sposób na przystosowanie się do nowej sytuacji (Reber 2000).

Również uczniowie przekraczający kolejny próg edukacji wystawiają na próbę dotychczas opanowane techniki adaptacyjne, starając się odpowiedzieć na zmiany związane z procesem edukacji, systemem oceniania oraz oczekiwaniami nauczycieli. Te zaś najczęściej nie wpisują się w możliwości absolwentów niższych poziomów 
edukacyjnych, tym bardziej uczniów ze specjalnymi potrzebami i problemami edukacyjnymi. Przyczynia się to niejednokrotnie do spadku samooceny i wielu niekorzystnych zmian $w$ funkcjonowaniu psychospołecznym.

Trudności przystosowawcze wynikają m.in. z braku kompetencji społecznych, które z kolei silnie wiążą się z poczuciem wewnętrznej kontroli oraz z poczuciem skuteczności (Mudrecka 2013, s. 57; Łukasik 2013). To ostatnie pojęcie, wprowadzone przez Alberta Bandurę (2007), oznacza przekonanie jednostki, że poradzi sobie z konkretną, również nową sytuacją. Spostrzeganie własnej skuteczności określa myślenie, które motywuje, kieruje wykonaniem oraz emocjonalnym pobudzeniem (Łukasik 2013, s. 26). Nieprzystosowawcze formy funkcjonowania jednostki związane są również z przypisywaniem przez nią porażek przyczynom wewnętrznym, natomiast sukcesów - przyczynom zewnętrznym (Seligmann 1990, za: Mudrecka 2013, s. 58). Uczniowie ze specjalnymi potrzebami edukacyjnymi są w literaturze przedmiotu określani jako „szczególnie zagrożeni w zdobywaniu umiejętności społecznych” (por. Cytlak 2013, s. 180). Wobec powyższego ważne, by młody człowiek nauczył się ufać sobie i swojemu otoczeniu, osiągnął samokontrolę i poczucie własnej odrębności, wykształcił orientację na cele i inicjatywę w działaniu, zyskał poczucie własnej kompetencji i adekwatną samoocenę oraz nauczył się przebywać i współpracować w grupie rówieśniczej (Wiliński 2009, s. 194).

W niniejszym artykule postanowiono wskazać możliwości niwelowania wspomnianych trudności przystosowawczych uczniów poprzez rozwijanie ich kompetencji emocjonalnych, głównie inteligencji emocjonalnej. Wzięto przy tym pod uwagę fakt, że niski poziom inteligencji emocjonalnej może być zarówno przyczyną, jak i konsekwencją trudności przystosowawczych.

\section{OPIS STANU WIEDZY}

\section{TRUDNOŚCI PRZYSTOSOWAWCZE}

Trudności przystosowawcze to niezdolność przystosowania się do nieoczekiwanych zmian i nowej sytuacji życiowej, manifestująca się rozlicznymi formami zachowań, najczęściej nieakceptowanymi społecznie. Do typowych objawów należą: unikanie kontaktów z rówieśnikami, brak uznania w grupie rówieśniczej, obojętny lub niechętny stosunek do nauczycieli i obowiązków szkolnych, nastrój depresyjny, lęk, niska samoocena, poczucie braku możliwości poradzenia sobie w danej sytuacji, ograniczenie zdolności do wykonywania codziennych obowiązków, wybuchowość, regres, zachowania agresywne czy antysocjalne (por. Minkiewicz 2017, s. 162; Wolańczyk 2002, s. 23-24, 47-48). 
W literaturze przedmiotu odnaleźć można liczne badania dotyczące zaburzeń przystosowawczych uczniów ze specjalnymi potrzebami edukacyjnymi. I tak na przykład na zaburzenia przystosowawcze uczniów z dysleksją i innymi zaburzeniami w nauce w obszarze interakcji społecznych wskazują m.in. zajmowane przez nich niższe pozycje społeczne w klasie szkolnej, mniejsza akceptacja społeczna (odrzucenie bądź izolowanie przez rówieśników) niż w przypadku uczniów niemających problemów w nauce (Leszczyński 2008, s. 15; Gindrich 2002, s. 173-174). Uczniowie z trudnościami w uczeniu się wykazują nieadekwatne przystosowanie osobiste, są nadpobudliwi psychoruchowo, zamknięci w sobie (Leszczyński 2008, s. 16), wrażliwsi na niepowodzenia oraz skłonni do wycofywania się (Ledwoch 1999, za: Półtorak 2017, s. 76). Cechuje ich też wyuczona bezradność (Gindrich 2011). Uczniowie ci, chcąc zaistnieć na forum grupy klasowej, nierzadko posuwają się do zachowań niezgodnych z zasadami obowiązującymi w szkole (Mickiewicz 2011).

$\mathrm{Na}$ trudności przystosowawcze uczniów $\mathrm{z}$ wadami i zaburzeniami mowy, ich niższe poczucie wartości, brak wiary we własne siły, spadek motywacji do nauki i zadań szkolnych wskazują badania m.in. Barbary Sawy (1990) i Elżbiety Marii Minczakiewicz (2017, s. 161), która zwraca uwagę na to, że prawie 40\% tych uczniów jest izolowanych w klasie, a 18\% odrzuconych. Również dzieci ze specyficznymi zaburzeniami językowymi (SLI) mają niższą pozycję w strukturze socjometrycznej, rzadziej wchodzą w relacje społeczne z rówieśnikami i dorosłymi oraz wykazują mniejsze zdolności społeczne (Leonard 2006, s. 30-31).

Liczną grupę w polskiej szkole stanowią uczniowie przewlekle chorzy. Szacunkowo problem chorób przewlekłych (z wyłączeniem otyłości) dotyka 20-25\% uczniowskiej populacji (Woynarowska, Oblacińska 2014; Małkowska-Szkutnik, Mazur 2011). Przewlekła choroba dziecka wpływa niekorzystnie nie tylko na jego rozwój psychiczny czy fizyczny, ale również na przebieg procesu edukacji i sytuację społeczną ucznia w grupie rówieśników (Huygen, Kuis, Sinnema 2000; Nowicka 2001; Shiu 2004; Góralczyk 2009; Woynarowska 2010). Badania wykazały statystycznie większy poziom stresu szkolnego u dzieci z chorobą przewlekłą niż u dzieci zdrowych (Małkowska-Szkutnik, Mazur 2011), a także większą podatność na zaburzenia przystosowawcze i afektywne. Według ustaleń naukowców dzieci chorych przewlekle dotyczą problemy: obniżonej samooceny i zaburzeń zachowania (Lavigne, Faier-Rouman 1992; Maciarz 2006; Brosig, Mussatto i in. 2007; Woynarowska 2010), dużego lęku, niedojrzałości emocjonalnej, braku poczucia bezpieczeństwa, zaburzeń obrazu siebie i tożsamości, obniżenia poczucia własnej wartości, deprywacji potrzeb emocjonalnych oraz obniżenia motywacji do działania (Góralczyk 1996; Pecyna 2000; Ionica, Lucacela i in. 2006). Co ciekawe, również rodzeństwo uczniów przewlekle chorych narażone jest na zaburzenia przystosowawcze (Kondracka 2013, s. 59). 
Uczniowie z rodzin dysfunkcjonalnych, w których dochodzi do zaburzeń interakcji społecznych, przejawiają zaburzenia przystosowawcze, na co wskazują badania zarówno światowe, jak i polskie (Havighurst 1981, Sher 2000, Grzegorzewska 2011). Na przykład uczniowie z rodzin alkoholowych charakteryzują się niższą samooceną, poczuciem braku kontroli, słabą umiejętnością radzenia sobie w sytuacjach nowych lub zmieniających się w porównaniu z uczniami wychowującymi się w rodzinach bez tego problemu (Dąbrowska, Oleś 2016, s. 67). Zaburzenia emocjonalne i w zachowaniu oraz niską samoocenę ujawniają dzieci doświadczające permanentnego zagrożenia i deprywacji potrzeb psychicznych w domach rodzinnych (Żeromska-Charlińska 2012, s. 271). Również pochodzenie $\mathrm{z}$ rodziny niezamożnej określa warunki egzystencji dzieci, sytuuje je w sferze ubóstwa i braku perspektyw (Kiełb-Grabarczyk 2010, s. 86-87; Marzec 2001, s. 147; Cęcelek 2011).

\section{UCZEŃ Z ZABURZENIAMI EMOCJONALNYMI I PRZYSTOSOWAWCZYMI W SZKOLE}

W celu zobrazowania trudności, jakie są udziałem uczniów przejawiających zaburzenia przystosowawcze, posłużono się opisem przypadku. Przedstawiono wybrane aspekty psychospołecznego i edukacyjnego funkcjonowania ucznia klasy IV szkoły podstawowej. Problemy natury emocjonalnej znalazły swe odbicie w zachowaniu i funkcjonowaniu chłopca. Analizując podobne przypadki, należy pamiętać, że ważną rolę w genezie i kształtowaniu objawów odgrywają indywidualne predyspozycje i wrażliwość jednostki (Olechowska 2016, s. 253).

\section{OPIS PRZYPADKU}

Uczeń ma obecnie 13 lat i powtarza klasę IV. W bieżącym roku (2018) zdiagnozowano u niego, zgodnie z klasyfikacją ICD-10, mieszane zaburzenia zachowania i emocji F92.8. Zaburzenia te manifestują się niestabilnością emocjonalną, zachowaniami impulsywnymi, trudnościami w dostosowaniu się oraz przestrzeganiu ogólnie obowiązujących norm i zasad.

W kwestionariuszu osobowościowym uczeń zaprezentował znacząco podwyższony poziom jawnego niepokoju, wysokie napięcie nerwowe. W stosunku do wieku ma obniżoną dojrzałość społeczno-emocjonalną. Z jednej strony jest niecierpliwy, w obliczu trudności rezygnuje z wysiłku. Z drugiej strony wykazuje pewność siebie, dominację, upór, bunt, krytycyzm wobec innych - lubi zwracać 
na siebie uwagę. Uczeń teoretycznie zna obowiązujące normy, na ogół jednak postępuje pod wpływem emocji, impulsywnie. Ma problemy z uznaniem autorytetu dorosłych i przewidywaniem skutków swojego postępowania. Nieletniemu orzeczono środek wychowawczy w formie nadzoru kuratora oraz zobowiązano go do uczestniczenia w zajęciach ośrodka szkolno-wychowawczego.

Rozwój chłopca przebiegał prawidłowo, został urodzony siłami natury. Adekwatnie do wieku nabywał kolejne umiejętności. Z uwagi na trudności wychowawcze po raz pierwszy został zgłoszony do poradni psychologiczno-pedagogicznej w klasie II szkoły podstawowej. Z opinii uzyskanej wówczas od wychowawcy wynikało, że umiejętności szkolne chłopca nie budzą zastrzeżeń. Był on określany jako uczeń zdolny i bardzo aktywny. Wychowawczyni wskazała natomiast na pewne symptomy trudności. Uczeń:

- nie kończył rozpoczętych prac, odmawiał ich wykonania,

- prezentował nierówne tempo pracy, miał problemy z koncentracją uwagi podczas zajęć,

- rozmawiając na lekcjach, przeszkadzał sobie i innym,

- miał problemy z panowaniem nad emocjami, reagował gwałtownie i niewspółmiernie do sytuacji,

- nie potrafił przegrywać i cieszyć się z sukcesów innych uczniów,

- popadał w konflikty z rówieśnikami, co przyczyniało się do braku akceptacji chłopca ze strony klasy,

- odnosił się niestosownie do nauczycieli i personelu szkoły,

- miał duże trudności z przestrzeganiem ustalonych zasad.

Po raz kolejny zgłoszono ucznia na diagnozę do poradni psychologicznopedagogicznej w klasie IV. Z opinii nauczycieli, wychowawcy i pedagoga szkolnego wynikało, że w sytuacjach emocjonalnie neutralnych, bezpiecznych uczeń wydawał się osobą towarzyską. Potrafił rozmawiać z innymi kolegami i nauczycielami, a w razie potrzeby zaoferować pomoc. W opinii nauczycieli chłopiec nie wykorzystywał posiadanego potencjału intelektualnego. Na podstawie informacji uzyskanych ze szkoły, m.in. od pedagoga szkolnego, który prowadził obserwacje, wskazano inne trudności. Uczeń:

- odmawiał wykonywania poleceń nauczycieli, nie wyjmował z plecaka książek i zeszytów, nie notował prac domowych,

- nie uczestniczył w wybranych lekcjach, wychodził samowolnie z sali,

- gdy spóźniał się na lekcje, pomimo próśb nauczyciela nie wchodził do sali, twierdząc, że nie lubi, gdy inni na niego patrzą,

- często łamał ogólnoszkolny zakaz korzystania na lekcjach z telefonów i tabletów. Nauczyciele wybierali „mniejsze zło” i nie reagowali na zachowanie chłopca, co z kolei rodziło bunt ze strony koleżanek i kolegów z klasy, 
- podczas wybuchów złości stosował groźby słowne w stosunku do rówieśników i nauczycieli,

- oszukiwał, próbował interpretować prawa i obowiązki na swoją korzyść.

$\mathrm{Z}$ uwagi na pogorszenie zachowania i brak promocji do klasy $\mathrm{V}$ uczeń poddany został diagnozie medycznej. Stwierdzono w niej wyżej wymienione zaburzenia zachowania i emocji o złożonej etiologii. Zgodnie z zaleceniami lekarskimi wskazano potrzebę nauczania indywidualnego w specjalistycznym ośrodku opiekuńczowychowawczym. Uznano, że ta forma edukacji stanowi szansę na dalszą naukę połączoną z terapią.

W bieżącym roku szkolnym (2017/2018) uczeń przebywał we wspomnianym ośrodku. Nauczyciele ze szkoły podstawowej, do której jest zapisany, realizowali $\mathrm{z}$ nim zajęcia $\mathrm{w}$ formie nauczania indywidualnego. Chłopiec bardzo chciał utrzymywać dalsze kontakty z kolegami z klasy. Wychowawca zadbał więc o to, by uczeń mógł brać czynny udział w imprezach klasowych i wspólnych wyjściach.

W opinii nauczycieli po roku indywidualnego nauczania widoczny jest progres w zakresie opanowanych przez ucznia wiadomości i umiejętności, ale motywacja chłopca do nauki pozostaje wciąż niska. Nadal zdarzają się sytuacje labilności emocjonalnej, próby przekraczania granic, zagadywania i odchodzenia od tematu lekcji.

Podjęte w ośrodku intensywne oddziaływania terapeutyczne, korekcyjne i edukacyjne wpływają pozytywnie na zachowanie i osiągnięcia edukacyjne ucznia. Chłopiec uczestniczy w zajęciach sportowo-rekreacyjnych, korekcyjno-kompensacyjnych i socjoterapeutycznych. Ośrodek jest w stałym kontakcie z matką ucznia.

Informacje zebrane zarówno od nauczycieli, jak i pracowników ośrodka pozwalają wnioskować, że warunkiem progresu w zachowaniu i funkcjonowaniu chłopca jest dalsza intensywna praca terapeutyczno-wychowawcza, szczególnie $\mathrm{w}$ zakresie przestrzegania zasad, granic oraz radzenia sobie z przeżywanymi emocjami.

\section{INTELIGENCJA EMOCJONALNA A FUNKCJONOWANIE SZKOLNE UCZNIÓW}

Rozwój emocji wpisuje się w zmiany zachodzące we wszystkich obszarach funkcjonowania jednostki. Warunkuje rozwój innych procesów psychicznych, stanowiących tło rozwojowe dla kształtowania się emocji (Gasiul 2007). Przeżycia emocjonalne motywują do określonego działania. Zmiany w procesach poznawczych i relacjach społecznych wpływają na sposób identyfikowania stanów emocjonalnych, a także wyrażania emocji i kierowania nimi. Określają też ich rodzaj i intensywność. Rozwój umiejętności wyrażania emocji uzależniony jest od oczekiwań społecznych, wcześniejszych doświadczeń oraz od relacji z innymi osobami (Bakiera 2009, s. 49). 
Źródło emocji stanowią bodźce zewnętrzne lub wewnętrzne. Typowy dla danej osoby sposób reagowania emocjonalnego utrwala się wskutek oceny jego efektywności. Wybierane są więc reakcje, które przynoszą jednostce spadek napięcia wewnętrznego, dają aprobatę grupy rówieśniczej, a czasem pozwalają uniknąć dezaprobaty ze strony dorosłych. Tak zwane przykre emocje to składowa naszej emocjonalności, dlatego ważna jest akceptacja własnych przeżyć emocjonalnych i okazywanie ich w odpowiedni sposób. Do zadań dorosłych należy pomoc uczniom $\mathrm{w}$ nazywaniu tych przeżyć i radzeniu sobie z nimi. Adaptacyjne radzenie sobie z emocjami jest możliwe poprzez stosowanie różnych strategii, wykonywanie ćwiczeń oddechowych i relaksacyjnych, uczestniczenie w zajęciach sportowych, a także działaniach wolontariackich (Bakiera 2009, s. 55).

Rolą osób zajmujących się na terenie szkoły udzielaniem wsparcia psychologiczno-pedagogicznego jest pomoc w zrozumieniu, rozpoznaniu i nazwaniu przeżyć emocjonalnych, jak również rozwijanie zdolności samoregulacji poprzez kształtowanie inteligencji emocjonalnej (Goleman 1997).

Inteligencję emocjonalna można najogólniej zdefiniować jako zdolność lub zbiór zdolności poznawczych do przetwarzania informacji emocjonalnych, a więc do odczytywania znaczeń emocjonalnych i uwzględniania ich w rozumowaniu i rozwiązywaniu problemów. Zdolności te stanowią podstawę rozwoju kompetencji pozwalających na efektywną regulację emocjonalną oraz dobre radzenie sobie w sytuacjach społecznych i zadaniowych. Kompetencje emocjonalne będą tu rozumiane jako konkretne umiejętności radzenia sobie w rzeczywistych sytuacjach życiowych, w których pojawiają się informacje emocjonalne. Wielość i różnorodność takich sytuacji uzasadnia używanie terminu kompetencja w liczbie mnogiej. Zarówno inteligencja emocjonalna, jak i kompetencje emocjonalne są dyspozycjami instrumentalnymi, decydującymi o możliwości efektywnego działania, pozostającymi ze sobą w związku. Inteligencja emocjonalna to zatem jeden z czynników warunkujących nabywanie kompetencji emocjonalnych (Matczak, Martowska 2011, s. 7-8).

W koncepcji Daniela Golemana (1999, s. 46) kompetencja emocjonalna jest rozumiana jako „wymierna umiejętność wywodząca się z inteligencji emocjonalnej”, umiejętność praktyczna ukształtowana w toku uczenia się, na bazie zdolności, które składają się na inteligencję emocjonalną. Tę zaś można uznać za poznawczy wyznacznik kompetencji.

W zakresie kompetencji emocjonalnych, zdaniem Carol L. Gohm i Gerarda L. Clore’a (2002), znajdują się:

- umiejętności komunikowania swoich emocji innym w sposób zgodny z osobistymi celami oraz społecznymi standardami;

- umiejętności zarządzania emocjami - wywoływania w sobie określonych stanów i nastrojów, które ułatwiają funkcjonowanie, przykładowo wyko- 
nywanie zadań i utrzymywanie relacji społecznych oraz wyciszanie niekorzystnych emocji;

- umiejętność podnoszenia własnego nastroju;

- umiejętności wpływania na stany emocjonalne innych osób, motywowanie, pocieszanie lub wprawianie w dobry humor (Matczak, Martowska 2011, s. 7-8).

Peter Salovey i John D. Mayer (2002, za: Knopp 2010) wyróżniają w strukturze inteligencji emocjonalnej cztery grupy zdolności. Są to:

- zdolności do spostrzegania emocji (własnych i cudzych) oraz ich wyrażania;

- zdolności do emocjonalnego wspomagania myślenia (do wykorzystywania emocji i niesionych przez nie informacji przy rozwiązywaniu problemów);

- zdolności do rozumienia i analizowania emocji;

- zdolności do kontrolowania i regulowania emocji.

Zdolności należące do dwu pierwszych grup składają się na doświadczeniową (experiential) inteligencję emocjonalną, natomiast zdolności należące do grupy trzeciej i czwartej - na strategiczną (strategic) inteligencję emocjonalną. Pierwszy z tych rodzajów inteligencji warunkuje efektywność odbierania, wykorzystywania i przekazywania informacji emocjonalnych, drugi zaś - sprawność metapoznawczej kontroli tych procesów (Knopp 2010, s. 52).

Kompetencje emocjonalne, powstające w toku emocjonalnych doświadczeń, służą rozwiązywaniu rzeczywistych problemów emocjonalnych pojawiających się w sytuacjach społecznych i zadaniowych, w które jednostka jest zaangażowana (Matczak, Martowska 2011, s. 7-8). Mayer i Salovey (1999, za: Knopp 2010, s. 53) wskazują, że kompetencja emocjonalna odnosi się do wiedzy i umiejętności, jakie jednostka - zdeterminowana przez inteligencję emocjonalną - zdobywa po to, by mogła funkcjonować w sposób adekwatny w różnych sytuacjach.

Osoby o wyższym poziomie kompetencji emocjonalnych lepiej radzą sobie w sytuacjach trudnych w środowisku szkolnym. Duża inteligencja emocjonalna może się przyczyniać do zmniejszenia intensywności negatywnych przeżyć, jak również sprzyja poszukiwaniu kontaktów towarzyskich, które potrafią obniżyć napięcie emocjonalne i zwiększyć możliwość uzyskania wsparcia społecznego (Jaworowska, Matczak 2008; Matczak, Knopp 2013). Wpływ inteligencji emocjonalnej na regulację stresu zależy od rodzaju sytuacji stresowej, czynnika sytuacyjnego, właściwości podmiotowych oraz świadomości własnych kompetencji emocjonalnych.

Poszczególne komponenty inteligencji emocjonalnej mogą facylitować społeczne funkcjonowanie w środowisku szkolnym, a także procesy uczenia się i rozwiązywania problemów emocjonalnych. W badaniach hiszpańskich wykazano dodatnią korelację między rozumieniem i zarządzaniem emocjami u uczniów a opiniami nauczycieli na temat adaptacji szkolnej dzieci (wyrażającej się wynikami w nauce, odrabianiem 
prac domowych i uczestniczeniem w zajęciach) oraz przekonaniem, że poradzą sobie w życiu (Mestre i in. 2006, za: Knopp 2010, s. 70-71).

Inne są również mechanizmy radzenia sobie przy przejściu ze szkoły podstawowej do szkoły średniej u uczniów o wysokiej i niskiej inteligencji emocjonalnej. Ci pierwsi rzadziej chodzą na wagary i mają lepsze oceny (Petrides, Fredrickson i Furnham 2004, s. 279), a nauczyciele wykazują mniej obaw o ich postępy w nauce czy zachowanie (Qualter 2007, s. 80). Wyniki niektórych badań potwierdzają, że dzieci potrafiące odczytywać emocje innych ludzi osiągają wyższy status społeczny wśród rówieśników (Cole, Putnam 1992, za: Knopp 2005, s. 224). Natomiast dzieci o wysokim napięciu emocjonalnym, doświadczające silnych emocji negatywnych, labilne emocjonalnie nie cieszą się sympatią rówieśników, a nawet są przez nich odrzucane (Stocker, Dunn 1990, za: Knopp 2005, s. 225).

Omawiając zagadnienie inteligencji emocjonalnej, należy pamiętać, że charakter reakcji między dzieckiem a otoczeniem jest dwukierunkowy. Konieczne wydaje się zatem dostosowanie oddziaływań środowiska do indywidualnych cech jednostki, co sprzyja rozwojowi jej zdolności emocjonalnych. Istnieje szereg programów wspierających inteligencję emocjonalną. Ich celem jest zwiększanie u dzieci i młodzieży szeroko rozumianych kompetencji społecznych oraz emocjonalnych poprzez uczenie rozpoznawania emocji, wyrażania ich i zarządzania nimi, a także rozwijanie zdolności rozwiązywania problemów oraz samokontroli. Do najczęściej wskazywanych programów edukacyjnych tego typu można zaliczyć: PATHS (Childhood Development Programme for School), Program Rozwoju Społecznego K-12 (Social Development Program K-12), Naukę o Sobie (Self Science). Klasyfikowane są one jako programy „uczenia się społecznego i emocjonalnego”, nie dotyczą sensu stricto inteligencji emocjonalnej. Badacze zajmujący się zagadnieniem podkreślają, że ze względów praktycznych korzystniejsze jest wprowadzanie do szkół tzw. programów celowych, wspierających nabywanie zdolności emocjonalnych i kompetencji społecznych (Elias i in. 1997, 2000; Liff 2003; Schilling 1996; Vandervoort 2006, za: Knopp 2010, s. 96-99).

Peter Salovey, John D. Mayer i David Casuso (2002) wskazują, iż po 2002 roku dane dotyczące możliwości stymulowania inteligencji emocjonalnej u dzieci i młodzieży poprzez oddziaływania edukacyjne dotyczą głównie programów tworzonych i realizowanych na potrzeby badań naukowych, a nie rzeczywiście funkcjonujących w procesie edukacji.

Niektórzy z badaczy uważają, że umiejętności społecznych i emocjonalnych należy uczyć na osobnych zajęciach, sekwencyjnie i przez długi czas (Defalco 1999; Elias i in. 1997, za: Knopp 2010, s. 103). Przykładem takiego programu jest „Trening inteligencji emocjonalnej u dzieci i młodzieży” (TIEDM) opracowany na zamówienie placówek oświatowych Montessori w Konstancinie-Jeziornej (Knopp 
2010, s. 103-104). Składa się on z pięciu części adresowanych do różnych grup wiekowych - od dzieci w wieku 4 lat po uczniów szkół średnich. Realizacja każdej z części trwa około roku szkolnego. Co trzy lata dziecko przechodzi kolejny etap treningu. Tematyka zajęć w poszczególnych częściach jest podobna i obejmuje następujące zagadnienia:

- integracja i współdziałanie,

- świadomość ciała,

- komunikacja niewerbalna,

- ekspresja emocjonalna,

- samoświadomość emocjonalna,

- więzi z innymi ludźmi oraz towarzyszące im emocje,

- stosunek do samego siebie i związane z nim emocje,

- sposoby radzenia sobie z emocjami negatywnymi,

- samoregulacja i kontrola emocjonalna.

Scenariusze zajęć dostosowane są do grupy wiekowej. Wykorzystuje się następujące metody pracy z grupą: opowiadanie historii i biografii, miniwykład, instruktaż poznawczy, odgrywanie ról, gry i zabawy, praca w małych grupach, techniki relaksacyjne, ekspresja przez sztukę. Skuteczności programu nie zweryfikowano w badaniach empirycznych, jednak stanowi on ciekawą propozycję (Knopp 2010, s. 108). Rozwiązaniem służącym rozwijaniu umiejętności społecznych i emocjonalnych może być wprowadzanie treści w ramach prowadzonych przedmiotów (zajęć artystycznych i sportowych, etyki, religii, języka polskiego, historii) i w związku z codziennym funkcjonowaniem szkoły. Nauczyciele poprzez bieżące monitorowanie oraz skuteczną komunikację powinni wspierać uczniów w codziennych sytuacjach tak, by rozwijali umiejętności związane z samokontrolą, samoregulacją i akceptowanym społecznie sposobem wyrażania uczuć. Poza tym bardzo ważne jest uczenie się przez dawanie osobistego przykładu. Nauczyciel, pedagog powinien więc stanowić wzór osobowy dla dziecka i sam charakteryzować się wysokim poziomem umiejętności emocjonalnych. Zdolność do rozpoznawania, rozumienia emocji i zarządzania nimi sprzyja bowiem budowaniu bardziej pozytywnych i satysfakcjonujących relacji z uczniami oraz tworzeniu środowiska edukacyjnego na fundamencie wzajemnego wsparcia (Madalińska-Michalak, Górska 2012). Zwiększa również szansę na to, by sami uczniowie traktowali się z większym szacunkiem, a ponadto mieli świadomość, że istnieje więcej niż jedno podejście do problemu i sposobu jego rozwiązania. 


\section{PODSUMOWANIE}

„Przestrzeń edukacyjna, która powinna być dla uczniów miejscem gromadzenia doświadczeń sprzyjających nabywaniu dojrzałości kompetencyjnej dla wielu z nich staje się miejscem niekorzystnych przeżyć blokujących psychospołeczny rozwój” (Michalak 2015, s. 120). Istnieje szeroki wachlarz sytuacji szkolnych, które wywołują u uczniów trudności przystosowawcze. O jakości przystosowania jednostki do wymagań życia i o efektywności, z jaką wykonuje stojące przed nią zadania decydują zdolności poznawcze oraz umiejętności radzenia sobie z innymi ludźmi i sobą, w tym z własnymi i cudzymi emocjami (Matczak, Martowska 2011, s. 5).

Jak wykazują badania prezentowane w niniejszej pracy, uczniowie z dysleksją, wadami i zaburzeniami mowy, chorobami przewlekłymi czy wywodzący się z rodzin dysfunkcyjnych (co oczywiście nie wyczerpuje listy uczniów klasyfikowanych do tej grupy) wykazują wspomniane trudności zarówno w płaszczyźnie indywidualnej, jak i społecznej. Te z kolei uwarunkowane są zarówno czynnikami wewnętrznymi (np. posiadanymi przez dziecko zdolnościami emocjonalnymi, osiągnięciami nabytymi na poprzednich etapach edukacyjnych), jak i czynnikami zewnętrznymi (m.in. aktywnym wsparciem rodziców, nauczycieli lub innych osób ważnych z punktu widzenia prawidłowego rozwoju dziecka).

Posiadanie przez dzieci i młodzież rozwiniętych kompetencji emocjonalnych warunkuje ich rozwój osobisty i społeczny oraz wpływa na umiejętność konstruktywnego i skutecznego funkcjonowania interpersonalnego. Pozwala na akceptowane społecznie wyrażanie własnych uczuć, radzenie sobie z nimi oraz rozpoznawanie uczuć innych osób (Wosik-Kawala 2013). Zgodnie z podejściem Saloveya i Mayera inteligencja emocjonalna stanowi pewien potencjał jednostki, z którego wyodrębniono kompetencje emocjonalne (wiedzę i umiejętności). Poziom kompetencji emocjonalnych człowieka zależy od rozwoju inteligencji emocjonalnej.

Osoby o wyższym poziomie inteligencji emocjonalnej lepiej niż inni radzą sobie $\mathrm{z}$ nawiązywaniem i podtrzymywaniem bliskich relacji interpersonalnych. Umiejętność regulowania i odczytywania emocji umożliwia uzyskanie większego wsparcia społecznego, co zwiększa tendencję do poszukiwania wsparcia w przyszłości (Knopp 2005, s. 225).

W tym kontekście rozwijanie inteligencji emocjonalnej dzieci i młodzieży, a także stymulowanie ich aktywności emocjonalno-motywacyjnej w warunkach współżycia klasowego jawi się jako ważne zadanie szkoły i pracujących w niej nauczycieli. Powinni oni podejmować działania zmierzające zarówno do niwelowania zachowań znamionujących trudności przystosowawcze, jak i do zapobiegania ich konsekwencjom w dorosłym życiu młodego człowieka. Warto więc wyposażyć nauczycieli w umiejętności rzetelnego rozpoznawania tego typu problemów oraz 
radzenia sobie w sytuacji ich wystąpienia. Konieczne wydaje się uświadomienie nauczycielom, że działania typu: wzmacnianie u uczniów ich mocnych stron, pracowanie na tzw. zasobach, budowanie adekwatnej samooceny, jak również umiejętności radzenia sobie w sytuacjach stresowych niewątpliwie przyczynią się do zmniejszenia zjawiska wykorzystywania przez uczniów nieakceptowanych społecznie i destrukcyjnych mechanizmów przystosowawczych.

Zgodnie z podejściem całościowym rozwijanie kompetencji emocjonalnych powinno obejmować całe środowisko szkolne, a nie koncentrować się tylko na poszczególnych uczniach. Nauczyciel, planując pracę, musi zadbać o to, by forma zajęć była dla ucznia atrakcyjna, a on czuł się podmiotem działań edukacyjnych.

\section{LITERATURA}

Bakiera L., 2009, Czy dorastanie musi być trudne? Warszawa, Wydawnictwo Naukowe Scholar.

Bandura A., 2007, Teoria społecznego uczenia się. Warszawa, Wydawnictwo Naukowe PWN.

Bilewicz-Kuźnia B., 2015, Przystosowanie psychospołeczne i współpraca rówieśnicza dzieci działających w małych grupach. W: J. Uszyńska-Jarmoc, M. Bilewicz (red.), Kompetencje kluczowe dzieci i młodzieży. Teoria i badania. Warszawa, Wydawnictwo Akademickie Żak, 185-204.

Brosig C.L. i in., 2007, Psychosocial Outcomes for Preschool Children and Families after Surgery for Complex Congenital Heartdisease. "Pediatric Cardiology", 28(4), 255-62.

Buchnat M., 2013, Przystosowanie szkolne dzieci sześcioletnich ze specjalnymi potrzebami edukacyjnymi. Leszno, Wydawnictwo Wyższej Szkoły Humanistycznej im. Króla Stanisława Leszczyńskiego.

Cęcelek G., 2011, Sytuacja szkolna dziecka z rodziny ubogiej. Warszawa, Wydawnictwo Akademickie Żak.

Ciarrochi J. i in., 2002, Adolescents Who Need Help the Most Are the Least Likely to Seek It: The Relationship Between Low Emotional Competence and Low Intention to Seek Help. "British Journal of Guidance \& Counselling”, 3(2), 173-188.

Cytlak I., 2013, Iluzje inkluzji? Uczniowie ze specjalnymi potrzebami edukacyjnymi w placówkach oświatowych. „Studia Edukacyjne”, 27, 173-184.

Dąbrowska E., Oleś M., 2016, Skłonność do zachowań autodestruktywnych a prężność psychiczna młodzieży z rodzin z problemem alkoholowym. „Sztuka Leczenia”, 1, $65-76$.

Doroszewska J., 1989, Pedagogika specjalna. Wrocław, Zakład Narodowy im. Ossolińskich. Gasiul H., 2007, Teorie emocji i motywacji. Warszawa, Wydawnictwo UKSW. 
Gindrich P.A., 2002, Funkcjonowanie psychospołeczne uczniów dyslektycznych. Lublin, Wydawnictwo UMCS.

Gindrich P.A., 2011, Psychospołeczne korelaty wyuczonej bezradności młodzieży gimnazjalnej z trudnościami w uczeniu się i zaburzeniami towarzyszącymi. Lublin, Wydawnictwo UMCS.

Gohm C.L., Clore G.L., 2002, Affect as Information: An Individual-Differences Approach. W: B.L. Feldman, P. Salovey (red.), The Wisdom in Feeling. Psychological Processes in Emotional Intelligence. New York, The Guilford Press, 89-113.

Goleman D., 1997, Inteligencja emocjonalna. Poznań, Wydawnictwo Media Rodzina. Góralczyk E., 2009, Dziecko przewlekle chore. Psychologiczne aspekty funkcjonowania dziecka $w$ szkole i przedszkolu. Warszawa, Wydawnictwo CMPPP.

Góralczyk E., 2008, Wspieranie dzieci przewlekle chorych i ich rodzin. W: B. Woynarowska (red.), Profilaktyka w pediatrii. Warszawa, Wydawnictwo Lekarskie PZWL, 343-362.

Grzegorzewska I., 2011, Dorastanie w rodzinach z problemem alkoholowym. Warszawa, Wydawnictwo Naukowe Scholar.

Havighurst R.J., 1981, Developmental Tasks and Education. New York, Longman.

Huygen A.C.J., Kuis W., Sinnema G., 2000, Psychological, Behavioural and Social Adjustment in Children and Adolescents with Juvenile Chronic Arthritis. "Annals of the Rheumatic Diseases", 59, 276-282.

Jaworowska A., Matczak A., 2008, Kwestionariusz Inteligencji Emocjonalnej INTE. Warszawa, Pracownia Testów Psychologicznych Polskiego Towarzystwa Psychologicznego.

Kaczan R., 2009, Wspomaganie rozwoju dziecka z ograniczona sprawnościa w wieku szkolnym. W: A.I Brzezińska i in. (red.), Droga do samodzielności. Jak wspomagać rozwój dzieci i młodzieży z ograniczeniami sprawności. Sopot, Gdańskie Wydawnictwo Psychologiczne, 150-192.

Kiełb-Grabarczyk D., 2010, Wpływ rodziny na system (anty)wartości współczesnej młodzieży. W: G. Durka (red.), Współczesna rzeczywistość w wybranych problemach społecznych. Kraków, Oficyna Wydawnicza Impuls, 81-94.

Klus-Stańska D., 2004, Adaptacja szkolna siedmiolatków. Olsztyn, Wydawnictwo UWM.

Knopp K., 2005, Rola inteligencji emocjonalnej w życiu człowieka. „Studia Psychologica”, 6, 221-235.

Knopp K., 2010, Inteligencja emocjonalna oraz możliwości jej rozwijania u dzieci i młodzieży. Warszawa, Wydawnictwo UKSW.

Kondracka J., 2013, Założenia rekreacji terapeutycznej i jej rola na podstawie badań przeprowadzonych $w$ wakacyjnym ośrodku rekreacyjnym Barretstown dla dzieci cierpiacych na choroby przewlekłe i zagrażające życiu. „Psychiatria i Psychologia Kliniczna”, 13(1), 58-66.

Lavigne J.V., Faier-Rouman J., 1992, Psychological Adjustment to Pediatric Physical Disorders: A Meta-Analytic Review. "Journal of PediatricPsychology", 17, 133-157. 
Leonard L.B., 2006, SLI - Specyficzne zaburzenie rozwoju językowego. O dzieciach, które nie potrafia mówić. Gdańsk, GWP.

Leszczyński R., 2008, Dysleksja jako ciagle aktualny problem pedagogiczny. „Nauczyciel i Szkoła”, 1-2 (38-39), 9-18.

Lubowiecka J., 2000, Przystosowanie psychospołeczne dziecka do przedszkola. Warszawa, WSiP.

Łukasik I., 2013, Poczucie własnej skuteczności we współpracy z grupa. Eksperyment pedagogiczny w przestrzeni akademickiej. Lublin, Wydawnictwo UMCS.

Maciarz A., 2006, Dziecko przewlekle chore. Opieka i wsparcie. Warszawa, Wydawnictwo Akademickie Żak.

Madalińska-Michalak J., Góralska R., 2012, Kompetencje emocjonalne nauczyciela. Warszawa, Wydawnictwo Wolters Kluwer Polska.

Małkowska-Szkutnik A., Mazur J., 2011, Funkcjonowanie w szkole uczniów z choroba przewlekła. „Problemy Higieny i Epidemiologii”, 92(2), 232-240.

Marzec H., 2001, Dziecko w rodzinie z ubóstwem materialnym. Łowicz, Wydawnictwo Mazowieckiej Wyższej Szkoły Humanistyczno-Pedagogicznej.

Matczak A., Martowska K., 2011, Z badań nad uwarunkowaniami kompetencji emocjonalnych. „Studia Psychologica”, 11(1), 5-18.

Matczak A., Knopp K.A., 2013, Znaczenie inteligencji emocjonalnej w funkcjonowaniu człowieka. Wydawnictwo Stowarzyszenia Filomatów Liberi Libri [pozyskano z: www.liberilibri.pl/matczak/item/download, dostęp: 14.04.2018].

Michalak R., 2015, Przestrzeń klasy szkolnej miejscem wykluczenia uczniów. Problemy adaptacyjne czwartoklasistów. „Studia Edukacyjne”, 34, 101-121.

Mickiewicz J., 2011, Dysleksja rozwojowa. Podstawy diagnozy i terapii. Toruń, Wydawnictwo TNOIK.

Minczakiewicz E. M., 2017, Dyslalia na tle innych wad i zaburzeń mowy u dzieci $w$ wieku przedszkolnym i szkolnym. „Konteksty Pedagogiczne”, 1(8), 149-169.

Mudrecka I., 2013, Wykorzystanie koncepcji resilience w profilaktyce niedostosowania społecznego i resocjalizacji. „Resocjalizacja Polska”, 5, 49-61.

Nowicka A., 2001, Psychospołeczna integracja dzieci przewlekle chorych w szkole podstawowej. Kraków, Oficyna Wydawnicza Impuls.

Olechowska A., 2016, Specjalne potrzeby edukacyjne. Warszawa, Wydawnictwo Naukowe PWN.

Petrides K.V., Fredrickson N., Furnham A., 2004, The Role of Trait Emotional Intelligence in Academic Performance and Deviant Behaviour at School. "Personality and Individual Differences”, 36, 277-293.

Qualter P. i in., 2007, Supporting the Development of Emotional Intelligence Competencies to Easy the Transition from Primary to High School. "Educational Psychology in Practice", 23(1), 79-95. 
Salovey P., Mayer J.D., Caruso D., 2002, The Positive Psychology of Emotional Intelligence. W: C. Snyder, S.J. Lopez (red.), Handbook of Positive Psychology. Oxford, OUP, 159-171.

Pecyna M.B., 2000, Dziecko i jego choroba. Warszawa, Wydawnictwo Akademickie Żak. Półtorak M., 2017, Psychospołeczne funkcjonowanie dzieci z dysleksją rozwojowa wybrane aspekty. „Głos - Język - Komunikacja”, 4, 68-78.

Reber A.S., 2000, Słownik psychologii. Warszawa, Wydawnictwo Scholar.

Sawa B., 1990, Dzieci z zaburzeniami mowy. Warszawa, WSiP.

Sher K.J., 2000, Charakterystyka psychologiczna dzieci alkoholików. W: L. Zbucka (red.), Badania nad dziećmi alkoholików. Warszawa, Wydawnictwo Państwowej Agencji Rozwiązywania Problemów Alkoholowych, 164-183.

Shiu S., 2004, Positive Interventions for Children with Chronic Illness: Parents' and Teachers' Concerns and Recommendations. "Australian Journal of Education", 48(3), 239-252.

Wolańczyk T., 2002, Zaburzenia emocjonalne i behawioralne u dzieci i młodzieży szkolnej w Polsce. Warszawa, Wydawnictwo Akademii Medycznej.

Woynarowska B., 2010, Wpływ chorób przewlekłych na rozwój, zachowania i sytuacje szkolna dzieci i młodzieży. W: B. Woynarowska (red.), Uczniowie z chorobami przewlekłymi. Jak wspierać ich rozwój, zdrowie i edukację. Warszawa, Wydawnictwo Naukowe PWN, 19-41.

Woynarowska B., Oblacińska A., 2014, Stan zdrowia dzieci i młodzieży w Polsce. Najważniejsze problemy. „Zdrowie Dzieci i Młodzieży. Wybrane Zagadnienia”, 2(38), 41-64.

Żeromska-Charlińska J., 2012, Uniwersalność postrzegania jakości form życia współczesnej rodziny. „Łódzkie Studia Teologiczne”, 21, 263-275.

\title{
FUNCTIONING OF A STUDENT WITH ADJUSTMENT PROBLEMS IN A SCHOOL ENVIRONMENT IN THE CONTEXT OF THE NEED FOR DEVELOPING EMOTIONAL INTELLIGENCE
}

\begin{abstract}
Crossing the next/subsequent level of educational system as well as challenges pupils meet at school every day cause unpleasant emotions/feeling and contribute to difficulties with their self-esteem, relations with other people and make it difficult to develop social skills. All that leads to an adjustment disorder.

According to the research presented in Polish and foreign literature, the pupils, including those with special educational needs, quite often have problems with acquiring social and emotional skills and have problems to adjust to or cope with individual stress or social life events. In the article, a case study of a primary school pupil diagnosed as having an emotional
\end{abstract}


and behavioral disorder is presented and analysed. The importance of developing social and emotional skills among pupils in an early stage of education is stressed.

Pupils with adjustment problems may be helped by developing their social skills/competences and emotional intelligence. The research proves that some emotional skills may be taught. Emotional intelligence may be controversial but in the future it will be seen how important it is in the life of an individual.

Keywords: adjustment disorder, emotional intelligence, social skills/competences, special educational needs 